\title{
A Method for Decreasing Magnetic Shaking Leakage from Separated Magnetic Shields by Combining an Additional Shaking Coil in Reverse Direction
}

\author{
R. Takahashi, Y. Nakashima, and I. Sasada* \\ Interdisciplinary Graduate School of Engineering Sciences, Kyushu Univ., 6-1 Kasuga-kōen, Kasuga-shi, Fukuoka 816-8580, Japan \\ *Faculty of Engineering Sciences, Kyushu Univ., 6-1 Kasuga-kōen, Kasuga-shi, Fukuoka 816-8580, Japan
}

\begin{abstract}
In actual magnetic shielding applications, having easy access to the internal space volume of the shield is essential. We propose a new model of the shield composed of two separate cylindrical halves with a flat extention. The leakage magnetic field is calculated by using the finite element method on several models of magnetic shields in which two configurations of the conductor location of shaking coils and the ratio of two shaking coil currents are used as design parameters. We found that using the combination of two shaking currents, one positive and the other negative, and adjusting their ratios was effective in reducing the magnetic leakage.
\end{abstract}

Key words: magnetic shield, separated cylindrical magnetic shield, magnetic shaking, CFRP magnetic tape composite, leakage field

\section{付加コイルによる分離型磁気シールドのシェイキング磁界漏洩低減法}

高橋理恵, 中嶋祥博, 笹田一郎*

九州大学大学院総合理工学府, 福岡県春日市春日公園 6-1 ( 816-8580)

*九州大学大学院総合理工学研究院, 福岡県春日市春日公園 6-1 (T 816-8580)

1 はじめに

我々の身の回りには地磁気や樣々な電子機器等から発生する 環境磁界が存在し，光のような環境下で生体磁気などの低周 波微小磁界を計測する際には高性能な磁気シールドが必要と なる．しかし，パーマロイ金属を用いた従来の磁気シールドで は, 重量やコストがかかるわりには数 $\mathrm{Hz}$ 以下の低周波磁界に 対して遮断性能が低いといった問題があった。

これに対し，著者らは高角形磁性材料であるコバルト系アモ ルファス磁性薄帯 Metglas2705M に磁気シェイキングを施す ことで, 増分透磁率が飛躍的に増大することを見出し，これを 低周波磁界の磁気シールドに適用することで大きなシールド効 果を得ることができることを既に報告している ${ }^{1)}$. 磁気シェイ キングを用いることにより , パーマロイを材料として用いた磁 気シールドと比較して, 少量の磁性薄帯で高いシールド効果を 得ることができ，形状を両端開口円筒形にすることでシールド 空間へのアクセスを容易にすることができる ${ }^{2)}$.さらには , よ りシールド空間へのアクセスを容易にする目的で分割型円筒形 磁気シールドも作製し，乥の性能を報告してきた ${ }^{3)}$.

また , アモルファス磁性薄帯とシェイキングコイルを軽量で 高剛性の CFRP(Carbon Fiber Reinforced Plastic) と一体化した アモルファス磁性薄帯/CFRP 一体化円筒形磁気シールドを提 案し, サンプルを試作し, 構造と基礎特性についても報告して (る ${ }^{4)}$.

我々は, 分割型円筒形磁気シールドを発展させ , 現在新たな 磁気シールドのモデルとして , 分離型磁気シールドを提案して (る ${ }^{5)}$.このシールドは, 高いシールド比を保ちながら内部空 間へのアクセスの容易性を高めたものである .

磁気シェイキングには磁性体の増分透磁率を増大させシール ド比を高くする利点があるが，同時に磁束漏洩を引き起こす
欠点もある . 漏洩磁界は微小磁界の計測に大きく影響するた め，できるだけこれが小さくなるようにシールドを設計しなけ ればならない . 特に , 分離型磁気シールドにおいてはシールド シェル間に大きな空隙を許容するため, 漏洩磁界が大きくなる というリスクをもち, 光のためこれを低減させる処置が必要と なる .

光の方法として , 付加コイルを用いて漏れをキャンセルする 方法が有効であることを前に報告した ${ }^{6)}$. これは , 既に出来上 がった磁気シールドに外部から磁性体とシェイキングコイル を付加し，シールド内部に組み込まれたコイルと付加したコ イルの 2 つを用いて逆位相でシェイキングをおこなうもので あった .

本論文では，この方法をさらに発展させ , シールド作製段階 で2つのシェイキングコイルを内部構造として組み込み，光れ に流す電流の比を調整することによって , 漏洩磁界を大幅に低 減できることを数值計算によって示す．また，樣々なモデルに 関する計算を基に，漏洩磁界の低減に適したシールドシェルの 構造やシェイキングコイルの配置, 光して 2 つのシェイキング 電流の電流比について検討した結果を報告する .

2 シェイキング磁束の低減法

本論文で検討する分離型磁気シールドは，Fig.1に示すよう に 2 つのシェルを離隔して設置するため, 生体磁気計測の際 は被測定者がシールド内部空間にアクセスしやすく，また，測 定のためのセンサも導入しやすいという特長がある . しかし 分離型磁気シールドの磁気シェルには端部があるため, シェイ キング電流による漏洩磁界が，一体である円筒型磁気シールド に比べて大きくなるという欠点があるので, 弚の対策が必要と なる .

Fig.2 , Fig.3 に , シェイキングコイルを 1 つ用いたときと 2 


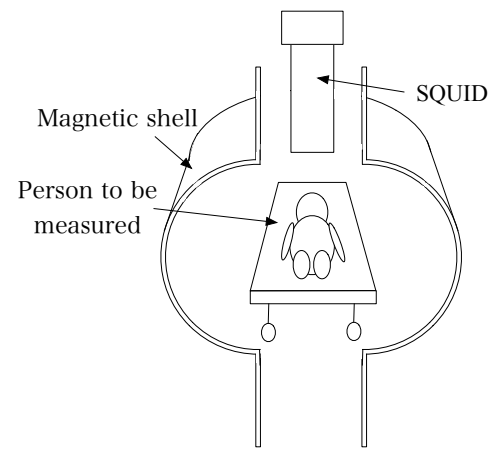

Fig. 1 Schematic of separated magnetic shield used to measure biomagnetic field.

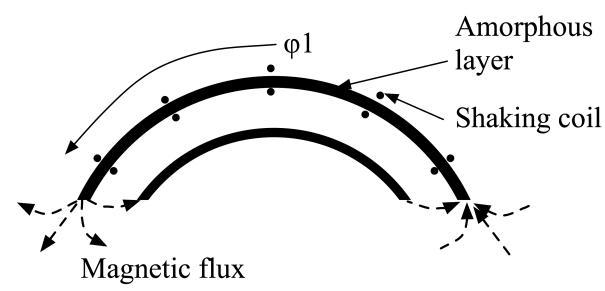

Fig. 2 Leakage of magnetic fluxes for single shaking current.

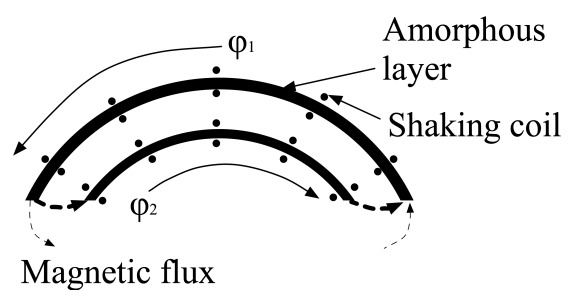

Fig. 3 Leakage of magnetic fluxes for mutually opposing shaking currents.

つ用いたときに生じる磁束の流れの概念图を示す . シェイキン グコイルが 1 つのときは, 磁束のバイパスの役割を果たす内側 のパッシブ層があっても磁束を全て集めることは難しく，磁束 は磁性体外部へ漏れてしまう．これに対して，Fig. 3 に示すよ うに 2 つのシェイキングコイルに互いに逆方向となるように電 流を流すと，漏洩磁界はキャンセルし合うので，これを小さく することができる．これが付加コイルを用いた実験で示された ことであり．本論文ではこの方法をさらに発展させ , 分離型磁 気シェルに一体としてコイルを組み込み漏洩磁界低減を図るも のである .

\section{3 分離型磁気シールドのシェル構造}

\section{1 磁性体層の構造}

今回検討した分離型磁気シールドは, 幅 $10 \mathrm{~cm}$ の平板状延伸 部をもつ長さ $60 \mathrm{~cm}$ の 2 つのシェルから成り，設置時の断面 構造が異なる 2 種である. Fig.4 , Fig.5 には，これらの構造を シールドの片側につき示している．ただし，各シェルの磁性体 層は実際は乥れ光れ厚みをもつが, 图中では構造が明確になる よう線のみで表現している. 各シェルの磁性層は, アモルファ 不磁性薄帯 (Metglas2705M) を多数積層することで作製するも

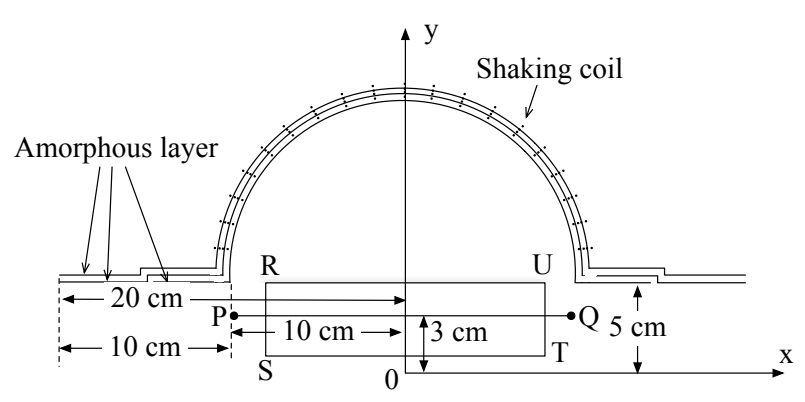

Fig. 4 Structure of magnetic shell shown for one half (elliptic type).

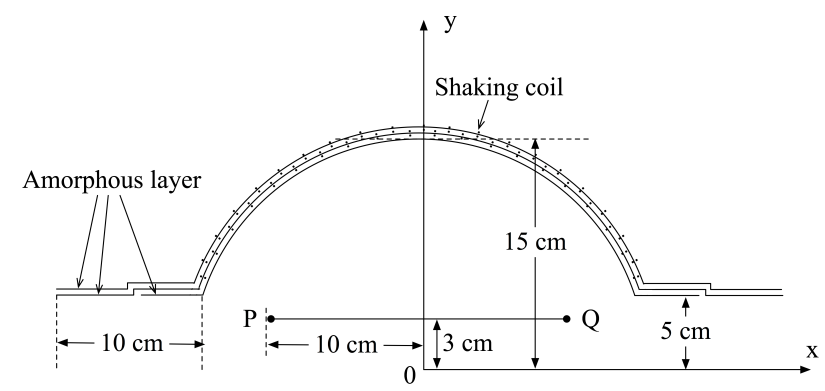

Fig. 5 Structure of magnetic shell shown for one half (circle type).

のとする . 各層の積層数は, 最内層を 110 (合計厚 $=2.2 \mathrm{~mm}$ ), 中央層を $110(2.2 \mathrm{~mm})$, 最外層を $100(2 \mathrm{~mm})$ とする.また， 图中の $x$ 軸は, 2 つ磁気シェルを組み合わせるときの対称面 の位置になっている (Fig.8, Fig.9 参照) .

Fig.4 の磁気シェルは , 主構造が半円形のものである . 今回 2 つのシールドシェルは $10 \mathrm{~cm}$ の空隙をあけて設置することを 想定したため, このシールド全体の断面構造は長軸 $30 \mathrm{~cm}$, 短 軸 $20 \mathrm{~cm}$ の略楕円型形状となる . 乥こで, 本稿ではこの形状の 磁気シールドを楕円型分離型磁気シールドと呼ぶこととする .

また , Fig.5 の磁気シェルは, 光の 2 つのシェルを離隔して 設置したときにシールド断面が円型となるものである . 本稿で は, この形状の磁気シールドを円型分離型磁気シールドと呼ぶ こととする.ここでも，2つのシールドシェルは $10 \mathrm{~cm}$ の空 隙をあけて設置することを想定し, 設置時の断面の直径が楕円 型分離型磁気シールドのシェル間に $10 \mathrm{~cm}$ の空隙をあけて使 用した時の断面の棈円の長軸の長さと等しくなるように , パラ メータを設定した .

3.2 シェイキングコイルのタイプ

シェイキングコイルの配置は , Fig.6 , Fig.7 に示す 2 つのタ イプについて検討する .ここで, 使用するシェイキングコイル は平角導線（厚さ $0.3 \mathrm{~mm}$, 幅 $1 \mathrm{~mm}$ ) としている.

Fig.6には, 2 つのシェイキングコイルの導体が半径方向同 一直線上に配置されるものを示している.このようなコイル導 体配置をコイルタイプ A と呼ぶものとする . シェイキングコ 


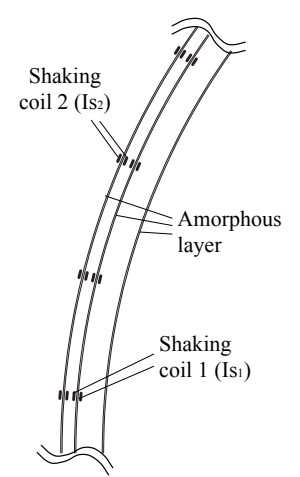

Fig. 6 Structure of corner part of one shell of shield (coil-type A).

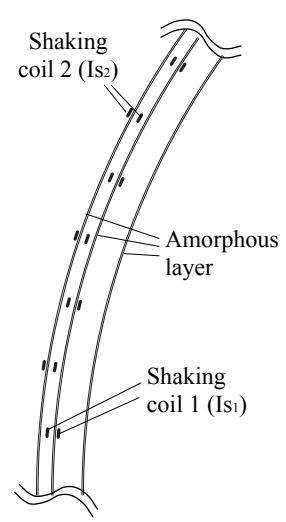

Fig. 7 Structure of corner part of one shell of shield (coil-type B).
イルは关れ光れのシェルについて , 中央磁性体層の周りに 19 ターン, 最外磁性体層のまわりに 19 ターン巻いている.しか し，コイルタイプ A では 2 つのコル導体を互いに絶縁して 重ねなければならず, 実際にシールドを作製するのが面倒で ある ・

乥こで, Fig.7 に示すような 2 対のコイル導体を交互に配置 するものも検討する .このようなコイル導体配置をコイルタイ プ B と呼ぶもものとする . コイルタイプ B では , 2 つのシェイ キングコイルの導体を最外磁性体層と中央磁性体層の間の中間 部に他の部分よりも本数を多く配置し, 内側のコイル対と外側 のコイル対が順番に並ぶようにしたものを示している．またこ のとき, 対称性を考えて, 内側と外側のシェイキングコイルの 巻数は, 外側のシェイキングコイルが 19 ターン, 内側のシェ イキングコイルが 20 ターンとしている .

\section{4 漏洩磁界の評価}

計算には有限要素法解析パッケージ COMSOL を用いた . 今 回は簡単のため, シェイキング電流を交流電流ではなく直流電 流とした直流解析を行う.

\section{1 計算方法}

今回検討した磁気シールドは全て境界 (Fig.4, Fig.5 の $x$ 軸) を挟んで対称な構造であるため, 有限要素法解析では片側の シェルのみ考えた . 2 つのシェイキング電流を印加したときに 生じる漏洩磁界は, Fig.4, Fig.5 中に示した線分 PQ 上で, 磁 束密度の絶対值で評価した。

印加するシェイキング電流について, 内側のシェイキング電 流 $1\left(I s_{1}\right)$ と外側のシェイキング電流 $2\left(I s_{2}\right)$ は互いに逆方向 としているが, 1 対の磁気シェルを考えるとき, 各磁気シェル を流れる磁束の向きの組み合わせは, Fig.8 及び Fig.9 の 2 通 りがある．乥こで $x$ 軸の境界条件は, Fig. 8 を考えるときはノ インマン型境界条件とし , Fig.9 を考えるときはディリクレ型 境界条件とした。

漏洩磁界の評価の際には, $I s_{1}$ に対する $I s_{2}$ の電流值の比を 変え, 光れによる漏洩磁界の変化を調べた . このとき, シェイ キング条件を同一に保つことが必要であるので, 今回は 3 層あ

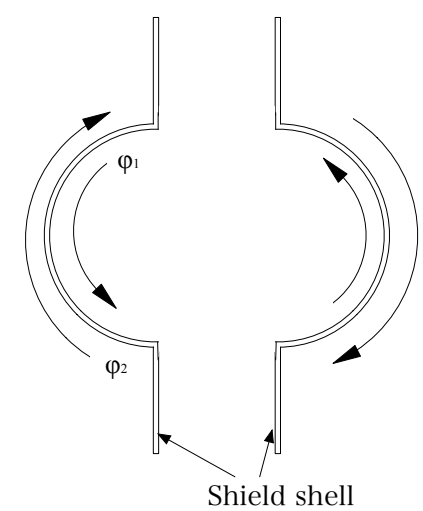

Fig. 8 Magnetic fluxes distributed in rotational symmetry.

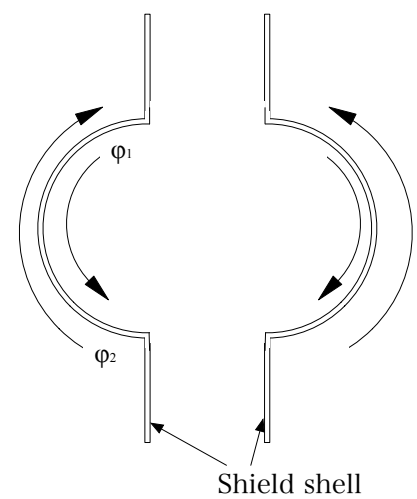

Fig. 9 Magnetic fluxes distributed in mirror symmetry.

る磁性体層のうち, 中央の磁性体層の磁束密度が $0.2 \mathrm{~T}$ となる ように計算結果に調整を加えた．つまり，線形モデルを用いて いるので, $I s_{1}: I s_{2}$ の比を一定に保ちながら双方を共に定数倍す ることによって,$y$ 軸上での中央の磁性体層の磁束密度が 0.2 $\mathrm{T}$ になるようにしたものである $.0 .2 \mathrm{~T}$ とは, 分離型磁気シー ルドが最も高いシールド性能を発揮するだろうと推測される近 傍のアモルファス磁性薄帯の磁束密度である.

また，磁性体の透磁率は50000 として計算した .

\section{2 計算結果}

楕円型でコイルタイプ A , コイルタイプ B の磁気シールド

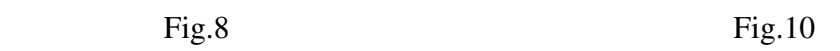
Fig.11 に示す . 図中の比は $I s_{1}: I s_{2}$ を表している .

Fig.10，Fig.11より，2つのシェイキング電流を用いること によってどちらも漏洩磁界が低減されており，漏洩磁界が最も 小さくなる $I s_{1}$ と $I s_{2}$ の最適電流比が存在していることがわか る .ここで, Fig.10 と Fig.11では, Fig.10の方が漏洩磁界は小 さくなっているが, 実用化に十分な性能と作製の容易性から, コイルタイプ B について検討を進めることとした .

円型でコイルタイプ B ,Fig.8 の配置で評価した結果を Fig.12 に示し，楕円型でコイルタイプ B ，Fig.9 の配置で評価した結 果をFig.13に示す.

Fig.10〜 Fig.13より，いずれの場合においても，2つのシェ イキング電流を用いることによる漏洩磁界低減効果が見られ， 漏洩磁界を最も小さくする $I s_{1}$ と $I s_{2}$ の最適電流比が存在して 


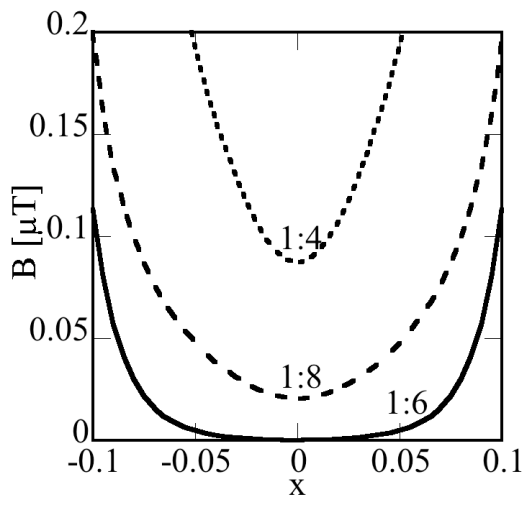

Fig. 10 Leakage field (elliptic type, coil-type A, rotational symmetry).

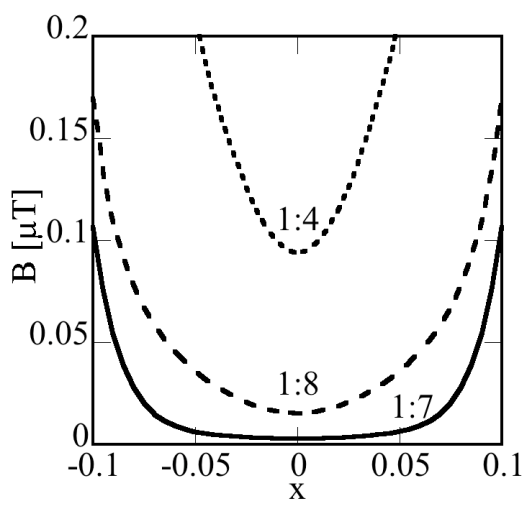

Fig. 11 Leakage field (elliptic type, coil-type B, rotational symmetry).

いた . 今回検討した構造における年の值は，I $I s_{1}: I s_{2}=1: 6$ の前 後であった . また , 楕円型かつコイルタイプ A で Fig.8 のよう に磁束が循環するように2つのシェイキング電流が流れる場合 が最も漏洩磁界が小さかった . しかし，楕円型かつコイルタイ プ B で Fig.8 のようにシェイキング電流を流す場合の漏洩磁界 も実用化に向けて十分な程の性能を示していた .

楕円型でコイルタイプ B , Fig.8 の配置の分離型磁気シール ドで $I s_{1}: I s_{2}=1: 7$ のときの計算によって得られた , 定めた位置 での磁束密度の絶対值を, 最も大きい值を 100 としてパーセン 卜表示したものを Fig.14 ,Fig.15 に示し ,Fig.4 中の範囲 RSTU における磁束密度のべクトル図を Fig.16 に示す . Fig.14 の横 軸の值は Fig.4 で設定した座標の $y$ 座標の值であり，Fig.15 の 横軸の值は分離型磁気シールドの中心から 45 度方向直線上で の位置である .なお，このときのシェイキング電流を中央磁性 体層の磁束密度が $0.2 \mathrm{~T}$ になるよう換算したときの值は, 内側 のシェイキング電流が $48.8 \mathrm{~mA}$, 外側のシェイキング電流が $342 \mathrm{~mA}$ である .

Fig.14 , Fig.15より，シェイキング電流によって磁性体部は 円周方向に沿ってほぼ一樣に磁化できていると考えられるた め, シェイキングによるシールド効果の向上が得られていると

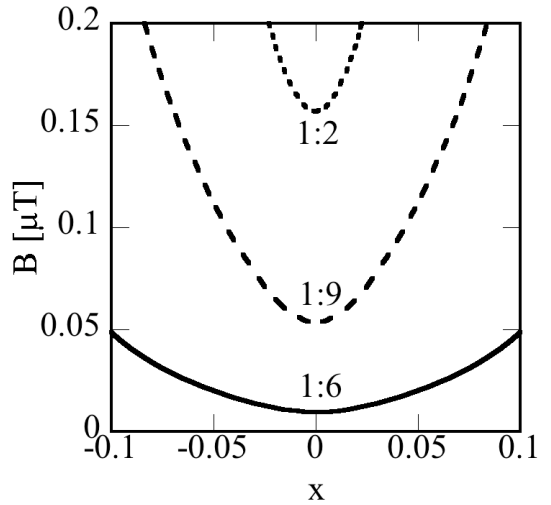

Fig. 12 Leakage field (circle type, coil-type B, rotational symmetry).

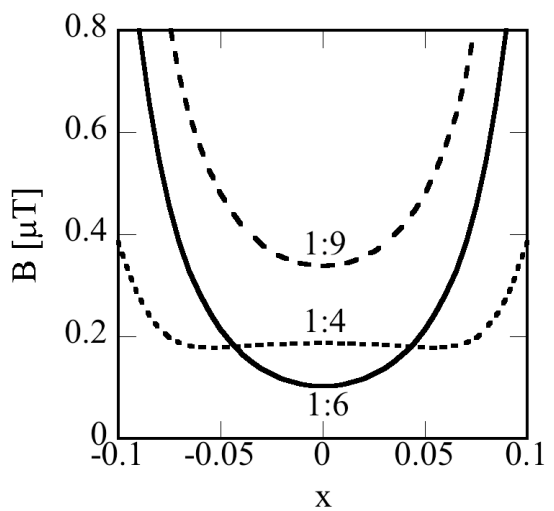

Fig. 13 Leakage field (elliptic type, coil-type B, mirror symmetry).

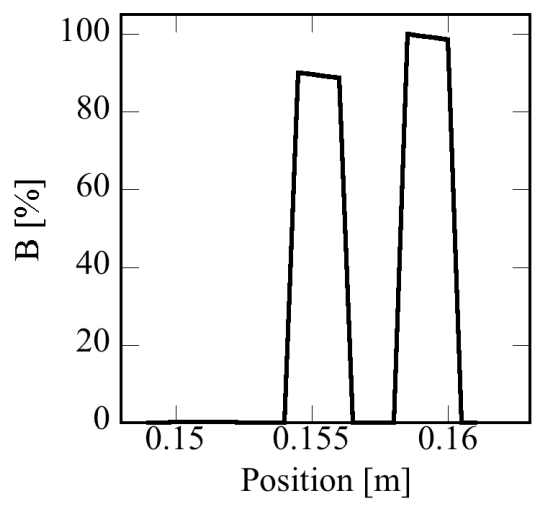

Fig. 14 Profile of magnetic flux density on y-axis(elliptic type, coil-type B, rotational symmetry, $I s_{1}: I s_{2}=1: 7$ ).

考えられる．磁束の集まり方は 3 層の磁性体層で光れ光れ異 なっていること, 漏洩磁界低減に最適な電流比時に最内磁性体 層の磁束密度はほぼゼロであることもわかる .さらに , Fig.16 より, 漏洩している磁束が磁気シェルの端部から生じ，もう一 


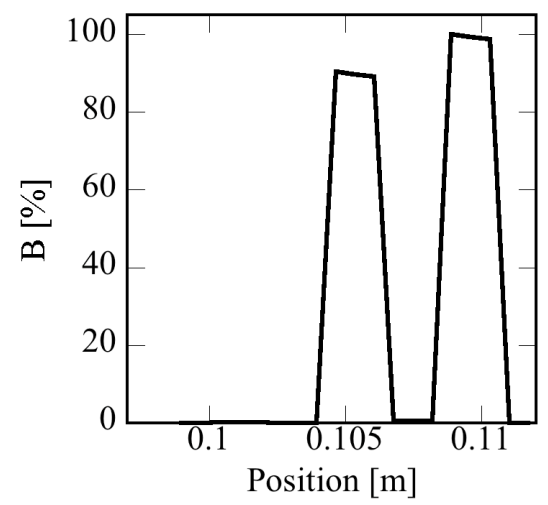

Fig. 15 Profile of magnetic flux density along 45-degree angle from $\mathrm{x}$ axis(elliptic type, coil-type B, rotational symmetry, $\left.I s_{1}: I s_{2}=1: 7\right)$.

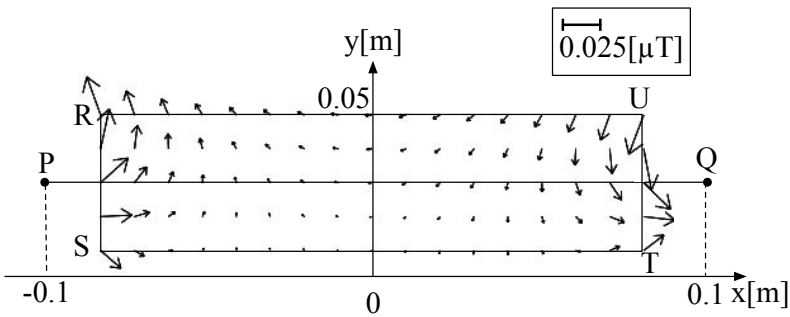

Fig. 16 Arrow plot of magnetic flux density in RSTU rectangle(elliptic type, coil-type B, rotational symmetry, $I s_{1}: I s_{2}=1: 7$ ).

方の端部へと向かっていること, シールド中心近傍での磁束密 度の值が小さいとがわかる．

評価は磁束密度の絶対値によりおこなったが , シールド中心 近傍ではこれはほとんど $x$ 方向の磁束密度 $B x$ によるものであ り, Byははぼゼロであった .

$$
5 \text { まとめ }
$$

今回 , 分離型磁気シールドにおいてシェイキング電流による 漏洩磁界低減のためのシェイキング法やコイルの配置, 磁気 シールドの形状を変えた樣々なモデルについて, 有限要素法を 用いて評価をおこなった .

異なった磁気シェルを互いに逆向きに励磁する 2 つのシェ イキング電流の大きさを変えることで, シェイキングによって 漏洩する磁界の大きさをコントロールできることがわかった .
また, 漏洩磁界低減のための最適電流比が存在することを示 した .

今回検討した分離型磁気シールドの構造モデルにおいて , 漏 洩磁界の低減効果が最大であったシェイキングコイルのタイプ は, コイルタイプ A であった .

しかし，実用上十分な性能を持ち，また作製の容易性から， コイルタイプ B について検討を進めた結果 , 形状が楕円型か つ Fig.8 の配置であるものが漏洩磁界の低減に適していた . ま た , コイルタイプ B の分離型磁気シールドでは, シェイキング 電流比 $I s_{1}: I s_{2}$ を $1: 7$ 程度にすることで , シールド中心近傍に おける漏洩磁界は $2.7 \mathrm{nT}$ 程度まで低減できることがわかった． ただし，この最適な電流比には, 最内磁性体層と中央磁性体層 間の距離が影響を与えることに留意する必要がある．

今後は, より磁束の漏洩を低減させることができるシールド 形状やコイル導体の配置, コイル巻数に関して, さらに詳しく 検討していく必要がある．また，現在は簡単のために計算は 直流解析でおこなっているので, この結果と実際用いる交流 シェイキングとの整合性についても検討していかなければなら ない.

計算によって評価されたシールド中心近傍での漏洩磁界は， ほとんど $x$ 方向の磁束によるものであり， $x$ 成分が $y$ 軸に対し 対称であるため, アキシャル構造 1 次微分型ピックアップコイ ルをこの対称面を考慮して配置すれば SQUID が観測する磁界 はキャンセルされる。したがって , Fig.1 のように插入される デュワー内に鉛直方向のアキシャル構造の 1 次微分型 SQUID を利用して生体磁気計測の実用化に向けて , 期待できると考え られる。

謝辞 本研究は科学研究費基盤研究 (A) の補助を受けおこな われた.

\section{References}

1) I. Sasada, S. Kubo, and K. Harada: J. Appl. Phys, 64, 5696 (1988)

2) I. Sasada, E. Paperno, and H. Koide: J. Appl. Phys, 87, 5959 (2000)

3) K. Tashiro, K. Nagashima, S. Sumita, T. Fukunaga, and I. Sasada: J. Appl. Phys, 93, 6733 (2003)

4) I. Sasada, T. Kimura, T. Takeda, and M. Shimada: Tech. on Magnetics, IEE Japan, MAG-05-94 (2005) (in Japanese)

5) I. Sasada: 2007 Natl. Conv. Rec. IEE Japan, Toyama, 2007, Pt. 2, p. 196 (The Institute of Electrical Engineers of Japan, 2007) (in Japanese).

6) R. Takahashi, T. Horie, and I. Sasada: Tech. on Magnetics, IEE Japan, MAG-07-28 (2007) (in Japanese)

2007 年 10 月 04 日受理, 2008 年 03 月 14 日採録 